\title{
Movimento operário, atuação e pensamento político-ideológico de Antonio Bernardo Canellas no Nordeste (1916-1920): um esboço interpretativo
}

\section{Bruno Rodrigo Tavares Araújo*}

Resumo: O artigo apresenta a trajetória político-ideológica de Antonio Bernardo Canellas no Nordeste, na segunda década do século XX, nas cidades de Viçosa e Maceió, ambas no estado de Alagoas e em Recife-PE. Sua trajetória, escrita e atuação no Nordeste permitem recuperar múltiplos elementos da história do movimento operário brasileiro fora do eixo Rio-São Paulo. A experiência e escrita de Canellas permitem evidenciar sua militância e posicionamento ideológico, acrescentando-se, ainda, aspectos referentes às mobilizações classistas interrelacionadas a outras cidades do país.

Palavras-chave: Antonio Bernardo Canellas; movimento operário; anarquismo.

Abstract: The article presents the ideological political trajectory of Antonio Bernardo Canellas in the Northeast Region of Brazil in the second decade of the 2oth century in the cities of Viçosa and Maceió, both in the state of Alagoas and Recife-PE. His trajectory, writing and performance in the Northeast allows us to recover multiple elements of the history of the Brazilian labor movement outside the Rio-São Paulo axis. The experience and writing of Canellas allows to show his militancy and ideological positioning, adding also aspects related to the class mobilizations interrelated to other cities of the country.

Keywords: Antonio Bernardo Canellas; labor movement; anarchism.

* Mestre em História pela Universidade Federal de Alagoas (UFAL). Professor do Instituto Federal de Alagoas, Campus Piranhas. 
Antonio Bernardo Canellas nasceu na cidade de Niterói, ${ }^{1}$ Rio de Janeiro, em 18 de abril de 1898 e faleceu em $1936 .{ }^{2}$ Foi militante e intelectual do movimento operário a nível nacional, regional (Nordeste, Sul e Sudeste) e internacional. Contemporâneo de Astrojildo Pereira, Octávio Brandão, Edgar Leuenroth, Cristiano Cordeiro, entre outros, como, por exemplo, Everardo Dias, amigo e companheiro de militância que fez a seguinte descrição de Canellas, no que se refere a sua personalidade, ideologia e atuação: ${ }^{3}$

Espírito irrequieto, comunicativo, pilhérico, mordaz, tinha amplo conhecimento do sindicalismo europeu e dos líderes mais em evidência. Voluntarioso e independente, irritadiço quando era contrariado, pouco infenso à disciplina partidária, mais se adaptava ao anarquismo do que propriamente ao comunismo. [...] A nossa convivência era polêmica ininterrupta não só a respeito de teorias e métodos de luta, como arte, filosofia, política em suas aplicações sociais. Esse era Canellas, que comigo conviveu vários anos, talvez os mais agitados de sua vida. ${ }^{4}$

Dotado de uma personalidade e história de vida enigmáticas, em razão de sua combatividade e ideais, migrou de Niterói-RJ para o Nordeste, Alagoas e Pernambuco, possivelmente por ser perseguido em sua terra natal. Chegou a Viçosa-AL em fins de 1915, com apenas 17 anos de idade, marco inicial de suas migrações e atuações que ocorreriam em Maceió, Recife, Rio de Janeiro, Porto Alegre e também por países da Europa, como a Espanha, França, Portugal e Rússia.

Autodidata, exerceu a profissão de tipógrafo, linotipista e gráfico. Divulgou as ideologias anarquistas, anarcossindicalistas, participou de sindicatos, chegando, inclusive, a integrar a Comissão Central Executiva do Partido Comunista Brasileiro, em 1922, sendo, inclusive, o primeiro militante expulso do Partido Comunista Brasileiro (PCB) no mesmo ano.

Um dos principais meios de atuação de Canellas se deu por meio da publicação dos periódicos: Tribuna do Povo, editado em Viçosa-AL, entre 1916-1917; A Semana Social, em Maceió, no ano de 1917; Tribuna do Povo, editada em Recife, entre 1918-1919; A Patuléia, de Porto Alegre; e o periódico Cinco de Julho (sendo uma de suas publicações de forma clandestina), totalizando cinco periódicos da imprensa operária editados por ele. ${ }^{5}$

Partindo do caminho percorrido por Canellas no Nordeste e acompanhando sua experiência, suas relações interpessoais, observando o contexto social, político, econômico e cultural das cidades em que vivera, é possível acompanhar e entender o desenrolar dos acontecimentos referentes às organizações,

1 Há poucas informações referentes à vida familiar de Canellas. Pela ausência de documentação, até o presente momento, pouco ou quase nada se sabe de sua infância e juventude.

2 Não se sabe exatamente a data e o motivo do seu falecimento. Segundo Moacir Sant'Anna, o falecimento de Canellas ocorreu em Portugal em consequência de um desastre automobilístico no ano de 1933. Cf: SANT'ANA, Moacir Medeiros de. História da Imprensa em Alagoas. Maceió: Arquivo Público de Alagoas, 1987, p. 38. Já Iza Salles informa que não é conhecido o dia, o local e quais foram os motivos da morte. Ver: SALES, Iza. Um cadáver ao sol. Rio de Janeiro: Ediouro, 2005, p. 197.

3 A descrição de Everardo Dias é uma dentre outras que apresentam algumas características de Canellas. No decorrer da pesquisa, observam-se mudanças em relação a sua personalidade e posicionamento político- ideológico nas descrições de seus contemporâneos de militância, como Octávio Brandão. Mudanças essas, fruto da maturidade, experiência e atuação do militante, possíveis de interpretação nas fontes e autobiografias dos militantes que conviveram com ele.

4 DIAS, Everardo. História das lutas sociais no Brasil. 2a ed. São Paulo: Alfa-Omega, 1977, p. 189.

5 É importante ressaltar que as atuações não ficaram restritas tão somente aos periódicos. A voz da militância de Canellas ecoou em sindicatos, reuniões, panfletos, representações e tantos outros meios quantos foram possíveis. 
mobilizações, lideranças, articulações entre militantes a nível nacional e internacional, mencionando, ainda, as ideologias e atuações dos sujeitos anônimos envolvidos no processo da história social do trabalho no Nordeste, ${ }^{6}$ oportunizando, também, uma compreensão da organização operária fora do eixo Rio-São Paulo nas primeiras décadas do século XX.

Assim sendo, a experiência de Canellas e as publicações de seus periódicos materializam essa oportunidade; a partir da contribuição com a imprensa operária em Alagoas e Pernambuco é possível identificar os entendimentos acima indicados. Os movimentos classistas tiveram nesse período (décadas iniciais da República) o mundo marcado pelo contexto internacional, que vivenciava a Primeira Guerra Mundial e a Revolução Soviética. No Brasil, tais acontecimentos influenciaram militantes e organizações classistas que optaram muitas vezes pelas greves gerais, entre outras ações contra as injustiças trabalhistas, sociais, políticas e econômicas do período.

Nesse contexto, e em estados marcados pela não receptividade de ideias progressistas, Canellas publicou seus periódicos voltados para a classe trabalhadora, que dialogaram com algumas tendências político-ideológicas da esquerda no período, predominando o anarquismo. Acerca do posicionamento político-ideológico de Canellas, existe uma polêmica historiográfica no que se refere à orientação político-ideológica do mesmo e de seus periódicos, com maior ênfase na publicação de A Semana Social.7

Tal polêmica é fruto das interpretações dos pesquisadores. Ao analisar as fontes documentais e seus periódicos, é possível encontrar algumas contradições entre a atuação, posicionamento ideológico, postura dos colaboradores como Magalhães Lima, Astrogildo Pereira, Neno Vasco, Octávio Brandão, ou seja, personalidades que transitavam entre o anarquismo e o socialismo, deixando em seus artigos princípios ideológicos e pragmáticos difusos.

Nesse sentido, Francisco Foot Hardman e Victor Leonardi caracterizam Canellas e o jornal A Semana Social como anarquistas, com uma ressalva de aproximação ou coincidência, ora com o anarcossindicalismo, ora com o socialismo revolucionário, ou ainda, com o socialismo libertário. ${ }^{8}$ Tendência compartilhada e possível de interpretação a partir, também, das pesquisas de Edilene Toledo, onde a mesma assevera que o sindicalismo revolucionário era uma tendência sindical que deixava livre a atuação político-ideológica dos sindicalistas e dos sindicatos. Ou seja, não havia medidas impeditivas para a participação de anarquistas. ${ }^{9}$

Ainda, em relação à polêmica historiográfica, Moacir Sant'Ana, historiador da imprensa alagoana, afirma que Canellas fora socialista. ${ }^{10}$ Contudo, outro historiador alagoano, Osvaldo Maciel, afirma que não encontrou tendência anarquista nas

6 A Região "Nordeste”, na época em que Canellas viveu, era retratada como Região Norte, em virtude, segundo Durval Muniz de Albuquerque Júnior, da antiga divisão regional do país entre Norte e Sul. Ver: JÚNIOR. Durval Muniz de A. A Invenção do Nordeste e outras artes. São Paulo: Cortez, 1999.

7 Em relação aos demais periódicos publicados no Nordeste (Tribuna do Povo de Viçosa e Tribuna do Povo de Recife), foi feita uma interpretação pelo autor do referido artigo, interpretação essa fruto da pesquisa acerca da trajetória e militância de Canellas no Nordeste, no recorte temporal estabelecido e dentro dos limites de uma pesquisa, onde se identificou uma contradição entre as publicações de matérias e defesas de Canellas em relação ao anarquismo e posterior aproximação e defesa do anarcossindicalismo. Entretanto, argumenta-se e defende-se pelo autor do referido artigo, que o posicionamento de Canellas no Nordeste foi predominantemente anarquista com uma transição para anarcossindicalismo em fins de 1920 no Recife-PE.

8 HARDMAN, Francisco Foot; LEONARDI, Victor. História da indústria no Brasil. 2ª ed. São Paulo: Ática, 1991, p. 233-4.

9 TOLEDO, Edilene. Travessias revolucionárias: ideias e militantes sindicalistas em São Paulo e na Itália (18901945). Campinas, SP: Editora da Unicamp, 2004.

10 SANT'ANA. História da Imprensa em Alagoas, p. 103-4. 
publicações do periódico A Semana Social e consequentemente em Canellas." Já Paulo Sérgio Pinheiro fez uma análise que situa Canellas em "evolução" do anarquismo para o comunismo.12 Edgar Rodrigues não reconhece o caráter anarquista do jornal e de Canellas, enquadrando-o no "socialista revolucionário". ${ }^{3}$ A autora Alice Plancherel, em sua pesquisa acerca de Octávio Brandão, afirma que Canellas comungava com as tendências anarquistas, assim como outros colaboradores dos seus periódicos.

Apesar das polêmicas, é consenso na maior parte das análises que Canellas posicionou-se como anarquista, sobretudo pelas suas constantes contribuições com o periódico A Plebe, de São Paulo. Após a pesquisa da trajetória e experiência de Canellas no Nordeste, que originou o presente artigo, identificou-se o mesmo como propagador das ideias anarquistas, com uma inclinação, na década de 1920, para o anarcossindicalismo.

Ainda em relação à pesquisa, e não restrita somente à polêmica historiográfica, mas ao cerne do estudo em que se concentra na trajetória, experiência, atuação, ideologia, intelectualidade, posicionamento político de Canellas, é possível afirmar que, numa perspectiva gramsciana, o mesmo atuou como um "intelectual orgânico". ${ }^{14} \mathrm{E}$ isto é posto por suas convicções ideológicas e atuações voltadas para a divulgação de autores, de textos, de argumentos de interesse de classe ao que ele dedicou-se durante toda sua trajetória política no Nordeste. Segundo Edmundo Fernandes Dias, o "intelectual no sentido gramsciano é alguém que está sempre interferindo na prática social”. ${ }^{15}$

A interferência social de Canellas, nos lugares onde militou, deu-se através das contradições ideológicas, ações, manifestações, divulgações, lutas, greves, associações em sindicatos, representações, viagens, produções escritas (quer seja em textos de sua autoria ou nas divulgações de outros autores, muitas vezes posicionamentos de sujeitos anônimos) e conhecimento do contexto social, político, econômico e cultural das cidades nordestinas em que vivera e que contavam com os movimentos operários, desmistificando a crença de que estes aconteciam apenas no eixo Rio-São Paulo.

Chegando a Viçosa-AL no final de 1915, Canellas encontra uma cidade forte economicamente. Na verdade,a segunda maior cidade do estado em razão do

11 MACIEL, Osvaldo. Trabalhadores, identidade de classe e socialismo: os gráficos e Maceió (1895-1905). Maceió: Edufal, 2009, p. 184-5.

12 PINHEIRO, Paulo Sérgio. Política e trabalho no Brasil. Rio de Janeiro: Paz e Terra, 1977, p. 109-10.

13 RODRIGUES, Edgar. Pequena história da imprensa social. Florianópolis, SC: Insular, 1997, p. 55.

14 Os intelectuais, para Gramsci, encontravam-se entrelaçados com as relações sociais, pois os mesmos fazem parte de uma classe e são vinculados a um determinado modo de produção (donos dos meios de produção). Essa última referência é em relação à designação de "intelectual orgânico" ou "intelectual tradicional". Os intelectuais tradicionais, para Gramsci, são basicamente os intelectuais ainda presos a sua formação socioeconômica (burguesa, clero, funcionários, militares, acadêmicos) e que exerceriam funções de manter a situação favorável à manutenção do status quo da classe da qual faziam parte. Eram "neutros", fechados num mundo enciclopédico, erudito, alheios às questões sociais decorrentes do sistema de produção e das lutas que envolvem o poder político e econômico. Já os intelectuais orgânicos, ao contrário, são os intelectuais que fazem parte de uma classe em expansão, que reivindica seus direitos e que não estão "neutros" frente aos problemas econômicos, políticos e sociais dos quais são vítimas. Estão conectados ao mundo do trabalho, às organizações culturais e políticas do seu tempo. Sendo assim, o intelectual orgânico é o que estabelece vínculo com a classe da qual faz parte ou representa, elaborando um posicionamento ético-político por meio de atividades educativas, culturais e organizativas no que se refere à emancipação política e social da sociedade. GRAMSCI, Antonio. Os intelectuais e a organização da cultura. Tradução de Nelson Coutinho $-4^{\text {a }}$ ed. Rio de Janeiro: Civilização Brasileira, 1982, p. 9-14.

15 DIAS, Edmundo Fernandes. “Intelectuais para que e para quem?” In: LOMBARDI, José Claudinei; MAGALHÃES, Lívia Diana Rocha; SANTOS, Wilson da Silva (Orgs.). Gramsci no limiar do século XXI. Campinas, SP: Librum Editora, 2013, p. 118. 
incremento da produção da cana-de-açúcar e algodão, que influenciaram o auge da cidade visualizada nas experiências sociais, políticas e culturais.

Para exemplificar a expansão, Brandão Sá16 apresentou as mudanças ocorridas a partir do incremento da produção de cana-de-açúcar e de algodão e do escoamento da mesma com a instalação da linha férrea, que marcou o desenvolvimento da cidade em aspectos sociais, econômicos e culturais. Numerosas construções surgiram entre 1890 e 1910, aberturas de novas ruas, instalação de escolas públicas e particulares, aumento populacional, surgimento de jornais de cunho burguês e religioso, fundação da Sociedade Instrutora Viçosense em 1894, fundação da Sociedade Amor e Caridade em 1903, fundação do Teatro Carlos Gomes em 1903, entre outros exemplos. ${ }^{17}$ Apesar dos avanços econômicos e culturais, os problemas sociais e políticos aumentaram e persistiram: altas taxas de analfabetismo, exploração de mão de obra operária e agrária, nepotismo, utilização do bem público para a manutenção de benefícios pessoais, autoritarismo político etc.

Nesse contexto, Canellas publica seu primeiro periódico, Tribuna do Povo, ${ }^{18}$ em 17 de agosto de 1916, totalizando 18 edições, ${ }^{19}$ sendo a última no dia 8 de janeiro de 1917. O jornal alcançou significativa projeção, sendo comercializado em cidades vizinhas: Pilar, Rio Largo e União dos Palmares. No primeiro número, Canellas publica no editorial a seguinte mensagem: “A 'Tribuna do Povo' o que somos e ao que vimos". No artigo, o autor apresenta o objetivo do jornal com as seguintes palavras:

Inicia hoje a publicação deste periódico. [...] As classes laboriosas vivem de um regime tirânico e antinatural. Não se eleva uma única voz em sua defesa, nem no seio do congresso, nem nas colunas da imprensa burguesa. Somos socialistas, amigos da liberdade e filhos do povo; vimos a pugnar pelos direitos dos oprimidos e assumir um posto de sacrifício. ${ }^{20}$

Nessa explanação, fica claro o posicionamento do redator em relação à defesa das classes menos favorecidas. É interessante observar o posicionamento do jovem Canellas (17anos) em uma cidade do interior de Alagoas, embora uma cidade com efervescência cultural e econômica. Desde o início, a proposta é divulgar as maleficências do regime político que, segundo o mesmo, oprimia a sociedade. Na mesma edição, o tipógrafo chama atenção ao regime republicano, segundo ele, falido, onde os representantes do congresso, em vez de cuidar da "salvação" do país, preocupam-se, tão somente, em aumentar impostos. No artigo "Sursum Corda!", o autor faz as seguintes ponderações:

Está proclamada a falência do regime republicano! [...] Resta, portanto, às classes produtoras apelarem para a ação direta - arma que torna inevitável um povo consciente - não confiando a defesa dos seus

16 SÁ, Eloi Loureiro Brandão. Viçosa cidade das Alagoas: formação e desenvolvimento. Maceió: Grafitex, 2000, p. 101-03. Segundo o autor, as transformações na cidade foram algo inédito em uma cidade do interior.

17 Para maiores informações referentes ao desenvolvimento econômico de Viçosa ver: (org.) Sociedade dos Amigos de Viçosa. Álbum do Centenário de Viçosa: 13 de outubro de 1831, 13 de outubro de 1931. Brasília: Plátano, 2008, p. 66-112.

18 O periódico foi publicado em formato tabloide, com quatro páginas, e custava 100 réis, avulso; sendo que, a partir de 7 de setembro (1916), passou a custar 200 réis. A publicação era semanal.

19 Das 18 edições publicadas, 16 encontram-se disponíveis no Centro de Documentação e Memória da UNESP (CEDEM).

20 Tribuna do Povo, Viçosa, 17 ago. 1916, p. 1. 
interesses a deputações de espécie alguma. [...] Quanto às providências dos homens do congresso, os agricultores devem ficar precavidos porquanto a ineficiência dos ditos está comprovada. ${ }^{21}$

Nesse artigo, Canellas tece o comentário observando as atitudes dos congressistas, mencionando a falta de apoio aos trabalhadores do meio rural, acrescentando os casos de denúncia de desvio de verbas e ações dos congressistas voltadas para a criação e aumento de impostos. Chama atenção, nesse posicionamento, a preocupação com a classe dos agricultores, algo não muito comum no período, talvez devido à cidade ter como principal fonte de economia a agricultura. No decorrer das publicações, o mesmo chama atenção para a necessidade de organização dos trabalhadores rurais, com paralisações e ações diretas para combater a exploração da qual eram vítimas.

Outro assunto bastante divulgado por Canellas em Viçosa foi correlacionado à Primeira Guerra Mundial, onde o mesmo fez vários comentários acerca dos interesses e objetivos da guerra, mencionando os verdadeiros motivos do conflito: o capital burguês, território, exploração de mão de obra barata e consequente crise econômica mundial e brasileira. Foram publicados vários artigos chamando atenção para os posicionamentos da imprensa burguesa, que propagava matérias de apoio ao conflito, como as de Olavo Bilac. ${ }^{22}$

Canellas também enfatizou, por meio de suas publicações no periódico viçosense, preocupações com o bem-estar social: reportagens acerca da importância do esporte enquanto meio de disciplina, de sociabilidade e interação; matérias referentes à carestia dos alimentos e sua escassez na mesa dos trabalhadores; informes gerais (de Viçosa e outras cidades do país, como Rio de Janeiro e São Paulo); foram publicados artigos de incentivos a leitura, teatro e cinema já presentes em Viçosa-AL. Chamam atenção, também, matérias correlacionadas às mulheres no que se refere à emancipação e capacidade de intelectual, algo não comum ao período, visto que o machismo ainda era recorrente.

Em relação aos posicionamentos políticos e ideológicos de Canellas, foram comuns publicações condizentes com seus ideais defendidos e divulgados. No artigo "O Grande Ideal”, é possível exemplificar:

Uma nova aurora começa a raiar nos horizontes do progresso! [...] Esse novo ideal é o Comunismo Anárquico! [...] O Comunismo Anárquico é a afirmação da liberdade completa do pensamento e da ação individual. [...] Compenetremo-nos de que, fazendo-se desaparecer a causa de todas as iniquidades - que é a autoridade ou domínio do homem sobre o homem - e adaptando-se a vida normal, a vida natural - que é o Comunismo Anárquico - um amor imenso penetrará no coração de todos os homens unindo-os por uma solidariedade generosa - e todos viverão vida integral. ${ }^{23}$

O que se pode observar nesse artigo é seu viés pedagógico, um meio de divulgar o conhecimento e aprendizagem acerca do anarquismo, observado, também, nas publicações dos colaboradores do jornal e teóricos tais como: Neno Vasco, Kropotkin, Elisée Reclus, Sebastien Faure, Proudhon, entre outros exemplos.

21 Tribuna do Povo, Viçosa, 17 ago. 1916, p. 1.

22 Segundo Canellas, o jornalista e poeta Olavo Bilac (1865-1918) defendeu o serviço militar obrigatório e fez campanhas em prol da participação do Brasil na Primeira Guerra Mundial. As observações do redator em relação ao poeta foram no sentido de chamar atenção para as consequências do "patriotismo" e da declaração de guerra por parte do Brasil.

23 Tribuna do Povo, Viçosa, 23 dez. 1916, p. 1. 
Na verdade, nas publicações da Tribuna do Povo em Viçosa, Canellas apresentase como divulgador das ideias anarquistas, citando e mencionando táticas para os operários e agricultores como meio de emancipação social e política, mencionando ações extraparlamentares, ação direta e o fim de organizações políticas burguesas capitalistas.

No que concerne às atuações propriamente ditas de Canellas em Viçosa, as mesmas se deram por meio das denúncias e incentivos em prol da organização social, embora não sendo encontrada alguma referência específica em relação à formação de sindicatos, associações de lavradores, greves etc. Todavia, ficou em evidência que existiram organizações de sociedades, embora não idealizadas por Canellas, mas compartilhadas por ele, nas divulgações, incentivos e participação, tais como: Sociedade Amor e Caridade e Sociedade Recreativa Instrutora Viçosense, que apresentavam suas atuações voltadas para as classes menos favorecidas.

Outro aspecto importante a ser observado na atuação de Canellas, em Viçosa, é sua aproximação e apoio às ações da Igreja Católica, quando o mesmo apoiava as ações da Associação Amor e Caridade. Algo contraditório para um anarquista, tendo em vista a caridade e poder da Igreja serem,teoricamente, contribuintes das mazelas do capitalismo. Acredita-se que tal apoio deu-se em virtude da juventude do militante e do não aprofundamento do conhecimento teórico, propriamente dito, acerca do anarquismo.

Devido a atuação de Canellas e a propagação de uma ideologia voltada para um projeto político emancipatório, suas denúncias dirigidas aos políticos locais, donos de fábricas e latifundiários culminaram com sua fuga para Maceió. Sua constante campanha contra a Primeira Guerra Mundial provocou as autoridades políticas e conservadoras de Viçosa-AL. Acredita-se, ainda, que ele migrou para Maceió vislumbrando a possibilidade de que uma cidade maior e com mais horizontes pudesse ser terreno fértil para levantes classistas pelos quais possuía elevado interesse. Havia, ainda, como motivo para a migração, a amizade com Octávio Brandão, nessa época seu companheiro de lutas e de ajuda mútua.

Na última edição do periódico Tribuna do Povo, em Viçosa, Canellas relata o porquê do fim das publicações e a consequente missão que pretendia continuar em Maceió-AL. Vejamos: “A ‘Tribuna do Povo’ suspende sua publicação”:

\footnotetext{
Depois de 6 meses de uma luta formidável, os que fazem a "Tribuna" confessam-se vencidos! Vencidos pelas dificuldades materiais; vencidos pela guerra que se faz à porta-voz da imprensa livre; vencidos pela impossibilidade de vencermos. [...] Temos consciência de que não nos afastamos do caminho que traçamos por ocasião do nosso primeiro número. Prometemos defender os interesses do povo e isto o temos feito quando dizemos ao povo que a defesa dos seus interesses não reside na ação eleitoral e sim na ação direta. Desejaríamos ter podido exercer uma ação mais vasta. Mas isso não podemos fazer dentro destes Dardanelos perigosos. Ficamos vencidos, mas não convencidos. Continuaremos a nossa obra em outra parte. O que não podíamos era continuar a lutar contra uma adversidade tão tenaz. ${ }^{24}$
}

Com o fim da publicação da Tribuna do Povo, Canellas encerra sua trajetória em Viçosa-AL, uma trajetória marcada por atuação e aperfeiçoamento de suas táticas e vivências em defesa dasdificuldades da classe trabalhadora e da afronta à realidade política local.

24 Tribuna do Povo, Viçosa, 8 jan. 1917, p. 1. 
Chegando a Maceió, Canellas se defrontava, realmente, com algo diferente daquilo que vivenciara em Viçosa. Definida em 1839 como a nova capital da província de Alagoas, ${ }^{25}$ essa mudança ocorreu em virtude da localização do porto do Jaraguá, local apropriado para exportação de produtos como madeira e algodão. ${ }^{26} \mathrm{E}$ a partir dela, iniciou-se o processo de urbanização ao longo do século XIX. Do mesmo modo, em decorrência do fortalecimento de grupos políticos pela economia açucareira, tornou-se então a principal municipalidade econômica e consequentemente demográfica da região.

A partir do século $X X$, ocorreram mudanças significativas no tocante à infraestrutura, relações sociais e políticas em Maceió-AL, como afirma Manuel Diegues Júnior. ${ }^{27}$ Segundo o mesmo, o início do século XX foi um período marcado pela expansão urbana, uma verdadeira mudança em relação à antiga cidade; surgem novas ruas, praças públicas, novos serviços etc. Félix Lima Júnior, ${ }^{28}$ em seus relatos do passado, com um tom de nostalgia, assim como Manuel Diegues Júnior falam sobre a antiga cidade e consequentemente das mudanças proporcionadas pelo advento da República.

No que se refere à sociedade maceioense, a mesma enfrentou os problemas advindos de um crescimento econômico no início do século XX. Problemas referentes à exploração de mão de obra (setor têxtil e férreo), analfabetismo, pobreza, busca de empregos na cidade em crescimento, desigualdades e problemas ainda existentes na atualidade - desigualdade social e problemas com a infraestrutura - somando-se às peculiaridades políticas.

Ainda hoje é possível observar que, nas questões concernentes à política, o estado alagoano mantém algumas características advindas de sua formação histórica. Como exemplo, podemos citar a origem histórica das relações estabelecidas por laços econômicos, iniciados no período colonial, período esse marcado por uma sociedade senhorial. Uma sociedade organizada em função da economia açucareira que manteve e mantém na política estruturas de dependência, troca de favores e falta de investimentos em outros setores econômicos que proporcionem mudanças sociais, econômicas eculturais. Entretanto, é necessário acrescentar que a política nacional durante a Primeira República foi marcada pelo coronelismo e pela política oligárquica, que segundo Edgard Carone ${ }^{29}$ "demonstrou ser a base estrutural da organização social, política e econômica da Primeira República (1889-1930)". Enfim, é nesse contexto sócio-político que Canellas publica A Semana Social, em uma cidade viva culturalmente e com muitas características advindas das relações humanas.

As publicações d'A Semana Social ${ }^{30}$ começaram no dia 30 de março de 1917, com as seguintes informações no seu cabeçalho: Anno I- $\mathrm{N}^{\circ} 1$, composto em oficina própria, MACEIÓ, 30 DE MARÇO DE 1917. Redação: Rua do Araçá nº 82. Pajussara. REDATOR - TIPÓGRAFO - ANTONIO CANELLAS.

25 BARROS. Theodyr Augusto de. O Processo de Mudança da Capital (Alagoas - Maceió): uma abordagem histórica, 1819-1859. Maceió: EDUFAL, 1991.

26 LINDOSO, Dirceu. "Ruptura e continuidade na cultura alagoana”. In: LINDOSO, Dirceu. A Interpretação da Província: estudo da cultura alagoana. Maceió: EDUFAL, 2005, p. 77-8.

27 DIEGUES JR., Manuel. “Evolução urbana e social de Maceió no período republicano”. In: COSTA, Craveiro. Maceió. Op. cit., p. 200/19.

28 LIMA JR, Félix. Maceió de outrora - v. 2 (org. e apresent. por Rachel Rocha). Maceió: EDUFAL, 2001, p. $19 / 65$.

29 CARONE, Edgard. A Primeira República (1889-1930). Corpo e alma do Brasil. Rio de Janeiro: Difel/Difusão Editorial, 1976, p. 67/128.

30 A coleção completa do periódico está depositada no Centro de Documentação e Memória - CEDEM UNESP. 
Com a publicação, Canellas dá continuidade ao que começara em Viçosa e sua trajetória e atuações são observadas no transcorrer de suas vinte e seis edições, sendo a última publicada em 3 de novembro de 1917. A Semana Social foi um jornal de grande repercussão em Maceió e nas cidades circunvizinhas (Rio Largo, União dos Palmares, Pilar, Viçosa, entre outras), sendo vendido, inclusive, em Aracaju$\mathrm{SE},{ }^{31}$ encaminhado aos militantes do Rio de Janeiro, enfim um jornal com circulação em âmbito nacional.

Desde a primeira publicação, Canellas divulgava informações educativas e elucidativas a respeito dos acontecimentos internacionais, nacionais, regionais e municipais. Em relação aos internacionais, o redator publicava frequentemente reportagens referentes à Primeira Guerra Mundial e Revolução Russa. ${ }^{2}$ Vejamos um de seus comentários e observações em relação à Revolução Russa33 na introdução do artigo: "A Revolução Russa suas causas e suas possíveis consequências":

[...] A explicação desse fenômeno obtém-se analisando-se com a lente realista do materialismo histórico os acontecimentos que há 30 meses estão se desenrolando sanguinolentamente no solo da velha Europa. Por mais superficial que seja tal análise, ter-se-á de constatar que a guerra da Rússia contra os impérios centrais é fruto da política da expansão eslava. [...] O povo russo precisa, sim, de um regime políticoeconômico equitativo e liberal para poder, então, seguir sua evolução normal até que sua cultura e a sua civilização transbordem para além de suas fronteiras pela palavra dos seus sábios e filósofos e pelo exemplo de sua organização social. ${ }^{34}$

Para Canellas, a Rússia não necessitava tomar parte na guerra para garantir expansão territorial, mas sim, era necessário que o povo russo adotasse um regime político-econômico baseado nos ideais da justiça e da liberdade e, de acordo com o editor d'A Semana Social, não seria derramando sangue que os russos chegariam a esse regime. ${ }^{35} \mathrm{O}$ correto, segundo o autor, seria lutar em prol de uma sociedade onde o imperativo fosse o respeito mútuo, a paz e a fraternidade universal, não permitindo que as mentiras burguesas e as ilusões patrióticas os dominassem.

Em A Semana Social, o nosso tipógrafo também levanta a bandeira da crítica à Primeira Guerra Mundial, da mesma forma e com a mesma veemência que empregou no periódico de Viçosa. Os artigos escritos eram didáticos, no sentido de trazer informações e de chamar atenção para as causas, objetivos, pretensões, manipulações, prejuízos e principalmente em relação às consequências para a sociedade que poderiam vir com a grande guerra. Nesse sentido, ele questiona acerca de quem de fato desejava a guerra e ao mesmo tempo responde-a. Acompanhemos sua elucidação:

31 O responsável pela venda e cobrança dos assinantes era o senhor Alberto Neno Pereira e o jornal era encontrado na agência da Companhia Singer, na Rua São Cristovam s/n, Aracaju-SE. A Semana Social, Maceió, 29 set. 1917, p. 3.

32 Artigos referentes à Revolução Russa e seus desdobramentos encontram-se no periódico. In: A Semana Social, Maceió, 30 mar. 1917, p.1/4; A Semana Social, Maceió, 10 abr. 1917, p. 1/4; A Semana Social, Maceió, 19 jun. 1917, p. 1/4; A Semana Social, Maceió, 11 jul. 1917, p. 3; A Semana Social, Maceió, 21 jul. 1917, p. 4; A Semana Social, Maceió, 8 set. 1917, p. 2.

33 A Revolução Russa influenciou as ideias, o imaginário, as expectativas dos militantes, quais sejam: comunistas, anarquistas, etc. As ideias, conceitos e posicionamentos dos militantes no período de 1917 a 1922 são marcados por posicionamentos confusos e vagos inicialmente, e por mudanças e rupturas até a fundação do Partido Comunista.

34 A Semana Social, Maceió, 30 mar. 1917, p. 1.

35 A Semana Social, Maceió, 30 mar. 1917, p. 1. 
Quem quer a guerra no Brasil? Não a quer o povo em geral. [...] Não a quer a classe operária [...] Não a quer a burguesia [...] Não a quer o conjunto do sexo feminino [...] Não a querem muitos capitalistas e industriais [...] Não a quer o chanceler da República [...] Não a querem os homens da ciência [...] E então, quem quer a guerra? Querem-na certos políticos sem escrúpulos que põem as suas simpatias por um grupo de beligerantes acima dos sagrados interesses do povo brasileiro. [...] Por isso, se os nossos dirigentes nos arrastarem à guerra, cometerão um crime social e trairão os nossos destinos. ${ }^{36}$

Esse foi um tema recorrente nas publicações do periódico, ${ }^{37}$ em consonância com a contextualização brasileira no que diz respeito aos desdobramentos e consequências da eventual participação. Essa temática, na realidade, já era discutida e posta em evidência. Segundo Moniz Bandeira, 38 "coube ao proletariado, agrupado na Confederação Operária Brasileira, lançar em 1915 a luta contra a guerra. O Centro de Estudos Sociais coordenou o movimento".

Ainda no que diz respeito à guerra, Canellas exibia em seus artigos o seu posicionamento de contrariedade à lei do sorteio militar obrigatório. ${ }^{39}$ De acordo com o redator, o sorteio do serviço militar obrigatório significava a mais completa desmoralização política, a estereotipação da falência da política dirigente, a negação do regime republicano. Canellas entendia a lei do sorteio militar obrigatório como uma maneira de "escravizar" o povo aos interesses da burguesia.

Outros assuntos debatidos, e, por que não dizer, colocados de forma pedagógica no sentido de divulgar conhecimento e aprendizagem através das páginas d'A Semana Social, corresponderam, sobretudo, aos movimentos classistas, tendo em vista que Canellas conclamava a classe dos trabalhadores rurais, talvez pela experiência em Viçosa, onde o mesmo presenciou e denunciou a exploração, falta de direitos e garantias da classe que, junto com os operários, deveria se organizar para derrubar o sistema vigente, visando à implantação de um sistema justo e igualitário.

Com isso, Canellas fez campanha com seus artigos iniciados em Viçosa e continuados em Maceió, ou seja, uma campanha antibelicista, que o tipógrafo vinha travando e alertando contra a participação do Brasil na Primeira Guerra. Seus posicionamentos culminaram com a revolta de uma parte da população maceioense que, em clima de patriotismo, voltou-se contra ele. Estava evidente que parte da população não compartilhava das críticas ao patriotismo feitas por Canellas, resultando em mais uma fuga. É nesse contexto que nosso redator deixa Maceió: para não ser morto pela população. ${ }^{40}$

36 A Semana Social, Maceió, 10 mai. 1917, p. 1.

37 Matérias referentes à Primeira Guerra Mundial: A Semana Social, Maceió, 20 maio 1917, p. 3/4; A Semana Social, Maceió, 30 mar. 1917, p. 3; A Semana Social, Maceió, 20 abr. 1917, p. 1; A Semana Social, Maceió, 30 abr. 1917, p. 3; A Semana Social, Maceió, 10 maio 1917, p. 1; A Semana Social, Maceió, maio 1917, p. 1; A Semana Social, Maceió, 30 maio 1917, p. 1/4; A Semana Social, Maceió, 9 jun. 1917, p. 1; A Semana Social, Maceió, 3 jul. 1917, p. 1; A Semana Social, Maceió, 11 jul. 1917, p. 2; A Semana Social, Maceió, 18 ago. 1917, p. 1; A Semana Social, Maceió, 25 ago. 1917, p. 2; A Semana Social, Maceió, 1 set. 1917, p. 3; A Semana Social, Maceió, 8 set. 1917, p. 1; A Semana Social, Maceió, 16 set. 1917, p. 3; A Semana Social, Maceió, 6 out. 1917, p. 4; A Semana Social, Maceió, 13 out. 1917, p. 1; A Semana Social, Maceió, 27 out. 1917, p. 1; A Semana Social, Maceió, 3 nov. 1917, p. 1/4.

38 BANDEIRA, Moniz; MELO Clovis; ANDRADE, A.T. O ano vermelho: a Revolução Russa e seus reflexos no Brasil. $2^{a}$ ed. São Paulo: Brasiliense, 1980, p. 41.

39 A Semana Social, Maceió, 20 maio 1917, p. 1.

40 Octavio Brandão narra a perseguição e o fechamento da sede do periódico "A Semana Social", que ocorreu provavelmente em 6 de novembro de 1917. Ver: BRANDÃO, Octávio. Combates e batalhas. São Paulo. Editora Alfa-Omega, 1978 (Memórias Vol. 1), p. 114/5. 
Acerca do movimento operário em Alagoas, Canellas, juntamente com os colaboradores, publicou vários artigos, chamando atenção para a necessidade de movimentos organizados como exposto no artigo: "Solidariedade, trabalhadores!". ${ }^{41}$ Nele, o redator deixa claro que os operários vivem em condições de dependência dos patrões, sem o mínimo de justiça e bem-estar social. Ele chama atenção em seu artigo para a necessidade de mudança, possível, segundo ele, com união e organização para ação e resolução dos problemas sociais, finalizando o artigo com a seguinte observação: "Solidariedade, trabalhadores!".

Teceu, também, muitas críticas ao sistema capitalista e consequentemente ao mundo burguês, responsável pelas atrocidades cometidas pelos mandatários que em nome da legalidade usurpavam o bem alheio. Nesse sentido, Canellas publica o seguinte artigo: "Belezas do mundo burguês, progresso atravancado", ${ }^{42}$ fazendo referência aos interesses dos capitalistas alagoanos que se utilizavam do governo para garantir suas posições e privilégios.

Em outro artigo, Canellas exemplifica bem os privilégios e bajulações aos capitalistas de Maceió: "Ferro em brasa... O comendador, o Jornal do Commercio e A Semana Social”, ${ }^{43}$ onde Canellas expõe sua indignação em relação às bajulações do Jornal do Commercio a favor do comendador Teixeira Bastos.44 Segundo Canellas, um explorador da classe trabalhadora recebendo imerecidamente a definição “Bastos, rei do trabalho e da benemerência!", por Zé Antonio, jornalista do Jornal do Commercio. A despeito de ser rico e poderoso, a figura do comendador Teixeira Bastos não impunha medo a Canellas, que estava sempre denunciando os abusos desse "benemérito do povo" e todos mais que ousassem abusar e cercear os direitos dos operários.

No que se refere aos operários, é possível identificar alguns indícios de organização e luta em Maceió pelo Comitê de Defesa Proletária, como descrito no artigo "Agitação obreira, uma grande manifestação em perspectiva":

As reuniões do COMITÊ DE DEFEZA [sic] PROLETÁRIA continuam a realizar-se sempre e nota-se entre os operários um firme propósito de levar adiante uma ação que lhes traga um pouco de bem-estar e que levante o moral da classe operária de Alagoas. [...] Nas reuniões do Comitê tem sido lembrada a necessidade real e imperiosa de organizarem associações de classe e é bem provável que elas surjam dentro em breve. ${ }^{45}$

Na edição de 20 de outubro, é feita uma convocatória indicando o lugar de um Comitê Operário em Maceió. O anúncio está descrito da seguinte forma: "PELA CLASSE OPERÁRIA", "Reúne-se amanhã, às horas da tarde, na Rua Voluntários da Pátria n 63, o COMITÊ DE DEFEZA PROLETÁRIA. Interesses da classe’. Não foi possível identificar nas fontes o número de participantes, todavia, mostra que houve organização operária, como descrito em outras matérias. Inclusive, cobrando do governo melhorias nos preços dos alimentos e divulgação de uma

41 A Semana Social, Maceió, 20 abr. 1917, p. 3.

42 A Semana Social, Maceió, 26 jun. 1917, p. 1.

43 A Semana Social, Maceió, 3 jul. 1917, p. 3.

44 Teixeira Bastos e os Zagalo eram duas das famílias mais importantes do estado alagoano, pertencentes à elite, ambas ligadas ao setor têxtil. Da primeira família, os Zagalo, não foi encontrada, até o momento, nenhuma informação, exceto, como já se disse, que era ligada ao setor têxtil. Quanto ao comendador Teixeira Bastos, era lusitano de Cabeceira do Basto, tendo imigrado para o Brasil e residindo durante aproximadamente meio século em terras alagoanas, onde funda e torna-se o principal acionista da fábrica Cachoeira, em Rio Largo.

45 A Semana Social, Maceió, 25 ago. 1917, p. 4. 
greve geral para conter as arbitrariedades existentes, no tocante às omissões frente às explorações dos donos das fábricas e das políticas públicas ineficazes.

A necessidade de associação e luta foi bastante divulgada por Canellas, citando casos de exploração e motivos para lutar, como se observa no seguinte artigo, "A necessidade de associação", que fala da exploração do proletariado sujeito a exaustivas 15/18 horas de jornada de trabalho por dia, estendendo-se aos domingos, noite adentro. Canellas fez a seguinte observação:

[...] Uma vez associados seremos uma força respeitada pelos governos e temida pelos industriais. Associados falaremos com voz forte ao Capital e ao Estado e conseguiremos realizar as nossas justas aspirações. Essas palavras são um convite à classe dos trabalhadores em fábricas de tecidos para associarem. Que os trabalhadores meditem e compreendam estas palavras! ${ }^{16}$

Ainda, denunciando casos de exploração, é mencionada a exploração de mulheres e crianças nas fábricas com jornadas excessivas de trabalho, informando,inclusive, o nome dos proprietários no artigo "Um crime social”:47

[...] Se se fosse fazer a estimativa das mortes causadas pela ganância industrial, chegar-se-ia à assombrosa conclusão de que, em número de vítimas, os terríveis personagens da galeria dos criminosos célebres estão aquém, muito aquém, dos Zagalo, dos Teixeira Bastos e dos demais donos de fábricas onde trabalham 15 horas por dia. ${ }^{48}$

É notória a contribuição de Canellas, por meio de seu periódico enquanto meio de divulgação e orientação para emancipação das classes trabalhadoras, conclamando a união e a organização dos trabalhadores em torno de seus interesses, somandose a propostas voltadas para conquista de uma sociedade justa e igualitária.

No tocante ao posicionamento ideológico de Canellas em Maceió e consequentemente dos questionamentos levantados no periódico A Semana Social, é possível afirmar que o mesmo posicionou-se com princípios anarquistas. Interpretação que parte das análises feitas desde a publicação da Tribuna do Povo em Viçosa-AL e continuidade nas publicações d'A Semana Social em Maceió.

Na capital alagoana, o periódico teve repercussão e boa aceitação junto à pequena burguesia, com as camadas médias e populares, chegando a ser aceita, também, no interior do estado. Diante da conjuntura internacional e nacional, os governantes alagoanos e de outros estados tomaram medidas repressivas e cooptantes para conter ou acabar com as projeções das classes trabalhadoras que vinham ampliando as organizações em torno do movimento operário no Brasil inteiro.

Canellas não permaneceu imune às medidas de repressão e violência. Sua atuação político-ideológica incomodou e sua contundente contrariedade à Primeira Guerra e a não aceitação ao patriotismo divulgado pela imprensa burguesa custou sua perseguição, apedrejamento da sede do jornal A Semana Social e sua saída para Recife, para não morrer em solo alagoano, como já foi mencionado anteriormente. Entretanto, sua atuação, persistência, audácia e luta ganharam um novo fôlego na capital de Pernambuco, com mais maturidade ideológica, 
experiência e combatividade junto à classe trabalhadora em oposição ao sistema burguês.

Em Recife, Canellas publica seu terceiro periódico, Tribuna do Povo(1918-1920). $\mathrm{Na}$ época, Recife era uma das cidades mais importantes do país, juntamente com São Paulo, Salvador e Rio de Janeiro. Segundo Antonio Paulo de Morais Rezende, nas duas primeiras décadas do século XX, a cidade apresentava os seguintes dados referentes à população e estabelecimentos industriais:

Em 1900 [Recife], tinha uma população de 113.106 pessoas, passando para 238.843 em 1920; haviam sido instaladas cerca de 113 estabelecimentos industriais, enquanto entre 1900 e 1909, mais de 33 iniciaram suas atividades. 49

Recife, na verdade, destacou-se economicamente desde o período colonial, com a produção açucareira, algodoeira, suplantada posteriormente pela cafeicultura na Região Sudeste do país. Em virtude dessas atividades econômicas, Recife manteve uma projeção política e econômica a nível nacional. Para termos uma ideia, entre fins do século XIX e início do século XX, as ferrovias pernambucanas cobriam quase todo o território do estado, chegando aos limites com Alagoas e Paraíba.

Em virtude do crescimento e desenvolvimento das indústrias, da economia, das exportações, do crescimento demográfico, das relações trabalhistas, enfim, das relações sociais, surgiram inevitavelmente reivindicações das classes trabalhadoras ${ }^{50}$ como a de $1903,{ }^{51}$ mais organizadas e combativas, segundo Rubim Santos Leão de Aquino:

Em 1903, os operários da The Great Western of Brazil Railway Company Limited paralisaram os trens exigindo melhores salários e chegaram a ser ameaçados pelo cônsul inglês. O mesmo tipo de greve se repetiu em janeiro de 1909, quando os trens ficaram paralisados por 12 dias. [...] Já no final do governo do general Emídio Dantas Barreto (19111915), surgiram greves. Os trabalhadores, sem terem perspectivas ou direitos, demonstravam insatisfação com a jornada de trabalho, que variava de 10 a 14 horas e com baixos salários arbitrados pelos patrões, aumentavam suas reivindicações..$^{52}$

Nesse contexto, Luiz Otávio Cavalcante apresenta três episódios que marcaram a segunda década do século XX em Pernambuco, atingindo seu ápice no final da segunda década (1919-1920), período em que Canellas reside, publica e atua junto aos movimentos classistas. Segundo o autor, os períodos foram os seguintes:

[...] O primeiro, em 1914, foi a criação da Federação Operária de Pernambuco, animada por incansável militante social, o estivador José

49 REZENDE, Antonio Paulo de Morais. "A classe operária em Pernambuco: cooptação e resistência (19001922)". (Dissertação de mestrado em História, Universidade Estadual de Campinas, 1981, 207 f.), p.42-3.

50 As reivindicações começaram desde o período imperial, segundo Antonio Paulo de Morais Rezende. O autor cita uma greve dos trabalhadores do porto em 1812, outra em 1880 dos tecelões da fábrica de Madalena; em 1902 ocorreu a greve dos ferroviários e remadores, sem falar da instituição da Imperial Sociedade dos Artistas Mecânicos e Liberais de Pernambuco, fundada em 1836. Para aprofundamento, ver: REZENDE. “A classe operária em Pernambuco", p. 16-17.

51 Com relação à organização da classe operária em Pernambuco no início do século XX, José Francisco afirma que em 1906 surgiu o movimento sindical no Recife, ao mesmo tempo descreve a situação em que vivia a classe operária. Ver: VV.AA. "Manifestações operárias e socialistas em Pernambuco". In: Cadernos de História - Recife: UFPE/Dep. de História, 1987, (mimeo.), p. 104-5.

52 AQUINO, Rubim Santos Leão de; MENDES, Francisco Roberval; BOUCINHAS, André Dutra (Org.). Pernambuco em chamas: revoltas e revoluções em Pernambuco. Recife: Massangana, 2009, p. 210. 
Elias. [...] O segundo episódio, ocorrido no interior do Estado, constituiu grave ocorrência política conhecida como "hecatombe de Garanhuns". [...] O terceiro episódio, acontecimento de repercussão no Estado, foi a greve de operários da Pernambuco Tramways. [...] A agonia da República Velha talvez tenha começado em Pernambuco. ${ }^{53}$

Foi nesse clima, ambiente de efervescência e expansão da luta operária em Pernambuco, que Antonio Bernardo Canellas redige e divulga o periódico Tribuna do Povo. O referido jornal foi lançado em $1^{\circ}$ de março de $1918 \mathrm{com}$ a seguinte finalidade, "O que somos e ao que vimos":

Nós vimos continuar a obra que encerámos[sic] em Viçosa no ano de 1916 e que desenvolvemos mais amplamente em Maceió n’A SEMANA SOCIAL. Somos socialistas revolucionários e vimos espalhar a semente de nossos ideais no solo fecundo do Pernambuco glorioso. ${ }^{54}$

Canellas deixa em evidência a continuidade de seus objetivos, quais sejam continuar o que iniciou em Viçosa e Maceió (AL), e inflama o discurso ao expor a intenção de espalhar seus ideais socialistas revolucionários no "fecundo solo pernambucano". Para isso, fixa o logradouro da redação do jornal à rua Dr. Feitosa (antiga Estreita do Rosário) $n^{\circ} 227$, no $2^{\circ}$ andar. ${ }^{55}$

Na primeira publicação, deixa indícios que teria uma atuação firme e forte, e nesse sentido seus artigos e publicações assumem posicionamentos voltados para atuação e mobilizações classistas, conforme consta no artigo "A nossa política":

Somos sistematicamente contra todos os políticos dirigentes. A nossa missão consiste principalmente expor e agitar as novas ideias de remodelação social, formando o ambiente idealístico favorável à aplicação das mesmas. [...] Por todo mundo, o proletariado se encontra preparado para tomar a direção das coisas públicas a fim de dispô-las conforme os seus direitos e é vergonhoso que em Pernambuco os trabalhadores se encontrem ainda tão aquém desse estado de preparação. ${ }^{56}$

Em relação a mobilizações classistas, tece observações e reflexões não restritas tão somente a Recife. Na verdade, Canellas publicou matérias referentes aos movimentos operários em várias cidades do país, citando exemplos de ações e greves que ocorriam em São Paulo, Maceió, Rio de Janeiro, entre outras cidades e estados, como descrito na matéria "O que vae pela Parahyba", onde o mesmo comenta acerca da situação e envolvimento do operariado na luta classista, acrescentando os métodos que os mesmos deveriam adotar:

No vizinho estado da Paraíba, desenvolveu-se muito o gosto pela associação, sendo de esperar que nessa terra haja dentro em breve uma força operária respeitável e consciente. [...] O sindicalismo é o método de ação completamente independente da velha ilusão política tendo por fim conquistar tono[sic] ao Capital, sempre e sempre, até firmar a completa supremacia do trabalho. [...] Enfim, temos fé em que os obreiros da Paraíba saibam despir-se de todas as ilusões, livrar-se de todos os pastores, dispensar os <srs.drs. Advogados> e caminharem

53 CAVALCANTI, Luiz Otávio. Pernambuco: uma história política. Recife: Bagaço, 2013, p. 95.

54 Tribuna do Povo, Recife, 1 mar. 1918, p. 2.

55 Tribuna do Povo, Recife, 1 mar. 1918, p. 1.

56 Tribuna do Povo, Recife, 1 mar. 1918, p. 2. 
fortes e conscientes pela estrada laminosa e reta do sindicalismo revolucionário. ${ }^{57}$

É possível observar no posicionamento ideológico de Canellas uma clara indicação de tendência ao sindicalismo revolucionário como meio tático. $\mathrm{O}$ redator tipógrafo dá continuidade a suas críticas, principalmente relacionadas à política, ${ }^{8}$ aos acontecimentos internacionais, como a Primeira Guerra Mundial e a Revolução Russa, ${ }^{59}$ acrescentando críticas ao sistema capitalista, bem como ao antimilitarismo. ${ }^{60}$

Assim como em Viçosa e Maceió, Canellas no Recife chama atenção para a necessidade de organização e mobilização das classes trabalhadoras, sendo importante citar que o mesmo mantém uma preocupação com a classe do meio rural ao destacar a vida difícil no campo, mencionando o descaso dos detentores dos meios de produção e dos representantes políticos a nível nacional. No artigo "A margem de um grande assunto", ${ }^{61}$ Canellas faz uma observação para a urgência na revisão das propriedades, conclamando pela necessidade de instrução, higiene e condições dignas de vida para os moradores do sertão e interior de Pernambuco.

Com relação aos operários, o militante divulgou as arbitrariedades às quais os mesmos eram submetidos no regime de exclusão e exploração em que viviam. Outras informações foram divulgadas acerca das perseguições e deportações de militantes. No artigo "As infâmias burguesas: Passou pelo Recife mais um dos operários deportados", ${ }^{62}$ é citado o caso de deportação do Sr. Francisco Aroca, em virtude de suas atuações e posicionamentos ideológicos.

Ainda em relação à classe operária, Canellas divulga informes referentes à necessidade de organização classista e sindical. Na matéria "O 'Centro Auxiliador de Classes Várias' ao operariado” é feita a seguinte convocação:

[...] Camaradas, nós estamos nesta triste situação porque o burguês conhece o estado de fraqueza em que nos achamos, porque ele sabe estarmos nós desorganizados. Porque se nós fossemos uma força decisiva na vida social desta terra não nos acharíamos nesse estado, pois todos teriam medo do nosso protesto e da nossa ação. No dia em que

57 Tribuna do Povo, Recife, 1 mar. 1918, p. 3.

58 Com relação à política, o redator continua chamando atenção para a "farsa" que eram as eleições, onde, na verdade, o que se tinha eram candidatos conservadores, oligarcas, escravocratas, enfim, "múmias" do passado.

59 A repercussão da Revolução Russa, as notícias, entre outras peculiaridades, eram divulgadas pela "grande imprensa" e pela imprensa operária. Como descrito por Canellas e atualmente conhecido, muitas informações eram distorcidas ou falsas. Isso para impedir a adesão e, consequentemente, a expansão para outros países, acrescentando o Brasil. $\mathrm{Na}$ verdade, ao longo das matérias publicadas, Canellas transmitia a repercussão e, ao mesmo tempo, uma "imprecisão" do que acontecia na Rússia, isso devido a seu posicionamento ideológico (anarquista). Para ele, a Revolução deveria ser seguida por todos e que os maximalistas eram exemplo a ser seguido. Em suas palavras, fica claro que a Revolução Russa seria um exemplo de socialismo anarquista, que, com o tempo, os sovietes iriam adotar os princípios anarquistas na condução e consolidação do processo revolucionário. Os artigos referentes à Revolução Soviética e seus desdobramentos encontram-se nas seguintes edições: Tribuna do Povo, Recife, 1 mar. 1918, p. 2; Tribuna do Povo, Recife, 10 mar. 1918, p. 2; Tribuna do Povo, Recife, 20 mar. 1918, p. 2; Tribuna do Povo, Recife, 10 abr. 1918, p. 2; Tribuna do Povo, Recife, 20 abr. 1918 p. 1; Tribuna do Povo, Recife, 10 maio 1918, p. 3; Tribuna do Povo, Recife, 20 maio 1918, p. 2; Tribuna do Povo, Recife, 10 jun. 1918, p.2 ; Tribuna do Povo, Recife, $10 a g o$. 1918, p. 2; Tribuna do Povo, Recife, 10 nov. 1918, p. 3; Tribuna do Povo, Recife, 1 dez. 1918, p. 3; Tribuna do Povo, Recife, 10 dez. 1918, p. 1/4; Tribuna do Povo, Recife, 20 dez. 1918, p. 1; e Tribuna do Povo, Recife, 1 jan. 1919, p. 1.

60 Canellas mantém o argumento contrário ao uso da força militar. No artigo "A investida alemã contra a Rússia, É preciso desarmar a Rússia", termina o mesmo dizendo que o militarismo é o mal do mundo, que deve acabar. Tribuna do Povo, Recife, 1 mar. 1918, p. 1.

61 Tribuna do Povo, Recife, 10 mar. 1918, p. 1.

62 Tribuna do Povo, Recife, 10 mar. 1918, p. 3. 


\begin{abstract}
um certo número de trabalhadores forem uma força ativa e consciente, pioneiros irredutíveis da sua causa, então sim, melhoraremos de vida... [...] Formemos, pois, entre a classe trabalhadora um número necessário de combatentes, de homens que saibam o que querem e o que devem fazer. E saiba-se que a associação de classe é a incubadora dos novos ideais, a Academia dos novos idealistas, e, portanto, é no sentido de fundar organizações que se devem dirigir os esforços de todos os trabalhadores que não estão de todo tapados pela inconsciência e que anseiam por uma vida feliz. Estes pequenos manifestos vão ser por estes dias distribuídos às várias classes trabalhadoras pelos camaradas do CENTRO. Parece que vai tornar-se um fato a organização do operariado pernambucano. ${ }^{63}$
\end{abstract}

Pelo exposto, torna-se evidente os passos iniciais da organização classista, inclusive com a divulgação de panfletos. É possível perceber a atuação de Canellas voltada para a organização sindical, ao mesmo tempo articulada com as mobilizações internacionais, sobretudo com a Revolução Russa, embora com indícios ideológicos voltados para o anarquismo, utilizando o sindicalismo como meio para mudar a sociedade, substituindo o estado e o capitalismo por uma sociedade autogerida pelos trabalhadores organizados.

No artigo "Vida operária", é sugerida a fundação de uma casa sindical para concentração de várias classes, como descrito na matéria. Vejamos:

Ocorreu-nos a ideia da fundação de uma Casa Sindical do Recife. Achamos de incalculável utilidade o funcionamento, em um só local, de todas as organizações operárias aqui existentes. [...] Essa circunstância de funcionarem todas as associações n'um só edifício provocaria entre elas um estímulo recíproco que seria bastante fecundo. Sobretudo, daria animação nas reuniões operárias hoje tão frias e estéreis. Além disso, havendo uma Casa Sindical desapareceria essa dificuldade hoje existente em se obterem locais para o funcionamento de associações decadentes ou em formação. Pode-se até dizer que essa dificuldade de se obterem locais é o que mais entrava a ação operária em Pernambuco. ${ }^{64}$

Artigos como esse, chamando atenção para a propaganda sindicalista, foram constantes nas publicações de Canellas. Interessante observar que, entre os anos de 1917-1920, surgiram algumas organizações sindicais a exemplo dos Sindicatos de Ofícios Vários, Sindicato da Construção Civil da Várzea e Confederação Operária de Pernambuco. Registra-se, também, a Sociedade de Alfaiates, União Operária de Afogados, Sociedade dos Marceneiros e Classes Anexas, Associação dos Artistas Civis, Sociedade dos Carpinteiros e Sociedade dos Estivadores.

Os incentivos e a postura adotada por Canellas em sua atuação e adesão às organizações sindicalistas de Pernambuco geraram frutos, ecoando mais uma vez em Alagoas. Com as publicações, visitas e esclarecimentos, surgiram outros sindicatos e associações naquela localidade. Em Pernambuco, surgiram a União dos Carvoeiros, União dos Fundadores e Agulheiros, Sociedade e União dos Estivadores, Fraternidade Gráfica, União Operária de Moreno, União Operária da Fábrica de Tecidos de Malha da Várzea, União de Resistência dos Trabalhadores em Armazéns e Carregadores de Pernambuco, União dos Estivadores, União Geral da Construção Civil, Liga de Resistência dos Cigarreiros etc. Com isso, começaram a

63 Tribuna do Povo, Recife, 10 mar. 1918, p. 4.

64 Tribuna do Povo, Recife, 1 abr. 1918, p. 3. 
ressurgir movimentos grevistas em Maceió, a exemplo das resistências do Recife, como os descritos na matéria, "De Alagoas":

É essa tática que está sendo adotada aqui em Pernambuco pela União de Resistência dos Trabalhadores em Armazém e pela União dos Fundadores e Agulheiros. [...] Os carpinas da ribeira e calafates declararam-se em greve exigindo o salário de 6\$000. A Casa Arsênio Fortes já atendeu às exigências dos trabalhadores, mantendo-se, contudo, o movimento grevista até as demais casas cederem também. Há indícios de estar próxima uma greve dos trapicheiros do Jaraguá. ${ }^{65}$

Essas mobilizações grevistas foram exemplos para as demais classes e incentivo para futuras mobilizações de caráter geral. E seus efeitos começam a ser visualizados pela propaganda e adesão à sindicalização, como ocorreu na cidade de Jaboatão-PE. Depois de uma visita da Organização de Defeza Proletária à Nathan, os operários reinstalaram o Sindicato de Ofícios Vários com a adesão de mais de duzentos operários, sendo esperado quadruplicar esse quantitativo, segundo Canellas. ${ }^{66}$

O movimento e organização classista tomaram uma proporção organizacional, chegando a utilizar e administrar o periódico Tribuna do Povo, que passou a ser responsabilidade da Federação de Resistência das Classes Trabalhadoras de Pernambuc0. ${ }^{67}$ A regulamentação e acordos da referida Federação foi transcrita na edição de 20 de novembro de 1918. Foi divulgado o artigo intitulado "Bases de acordo da Federação de Resistência das Classes Trabalhadoras de Pernambuco", ${ }^{68}$ que tratava da regulamentação da Federação no seu mais amplo sentido, destacando pontos como: Dos fins da Federação; Do ingresso para a Federação; Das resoluções da Federação e da Comissão Federal.

Um detalhe importante referente à Federação e à atuação de Canellas foi a viagem realizada por ele à Europa, representando a Federação de Resistência das Classes Trabalhadoras em uma Conferência Internacional Sindicalista que ocorreu em Paris, na França. A viagem ocorreu entre 21 de janeiro e 6 de setembro de 1919. Acerca da viagem, Canellas fez a seguinte conclusão a respeito de sua missão:

Os fins da minha ida à França eram, como disse atrás, estudar o movimento operário francês e tomar parte na Conferência Sindical. A primeira parte do meu programa realizei-a durante da minha estadia entre os camaradas franceses. A segunda não a pude realizar porque os recursos enviados do Brasil pelos camaradas, além de serem insuficientes para a viagem a Holanda, só chegaram 2 ou 3 dias depois da abertura da conferência. Portanto, nada mais me restava a fazer do que regressar e foi o que fiz aos 14 de agosto, pelo paquete Curvello. ${ }^{69}$

A viagem demonstra o envolvimento de Canellas com o sindicalismo, além de sua capacidade intelectual, a qual se compartilha do conceito gramsciano de intelectual orgânico e defende-se no referido artigo. É notória a atuação e amadurecimento

65 Tribuna do Povo, Recife, 1 jul. 1918, p. 4.

66 Tribuna do Povo, Recife, 1 set. 1918, p. 1.

67 Tribuna do Povo, Recife, 10 nov. 1918, p. 1.

68 Tribuna do Povo, Recife, 20 nov. 1918, p. 4.

69 CANELLAS, Antonio Bernardo. Relatório da viagem à Europa: realizada por Antonio Bernardo Canellas, em missão da Federação de Resistência das Classes Trabalhadoras de Pernambuco, 21 de janeiro a 6 de setembro de 1919. http://repositories.lib.utexas.edu/bitstream/handle/2152/20819/txu-oclc-45870016.pdf? sequence $=2$, acesso em 2014, p. 65 . 
ideológico, às vezes contraditório, mas que no conjunto de sua trajetória mantém bases sólidas da ideologia anarquista, embora não em sua especificidade.

Após o retorno de Canellas da Europa, o mesmo enfrentou uma série de acusações e perseguições, culminando com sua expulsão de Pernambuco em 1920. Para termos uma ideia, em janeiro de 1920, alguns jornais (Jornal do Recife, Jornal Pequeno, Diário de Pernambuco e A Província) publicaram informações referentes ao ostracismo do redator da Tribuna do Povo.

Em 12 de janeiro, foi publicada no Jornal Pequeno uma nota intitulada "O socialista Canellas" referente à expulsão do mesmo, vejamos: "A Polícia de Pernambuco expulsou, ontem, deste Estado, o agitador Antonio Canellas. O Dr. Luiz Correia, chefe de Polícia, encarregou dessa diligência o Dr. Manoel Cândido, delegado do $1^{\circ}$ Distrito, que levou a bom termo"..$^{70}$

A expulsão ficou em dúvida para alguns operários, tendo em vista o artigo "Teria sido deportado o operário Canellas". Segundo o artigo:

Ontem, à noite, estiveram em nossa redação dois operários, relatando-nos que o seu companheiro Antonio Bernardo Canellas havia sido deportado para o sul do país pelo "Macapá", que ontem mesmo zarpou com aquele destino. Adiantaram-nos ainda os referidos operários que a polícia conseguiu apanhar Antonio Canellas para a deportação atraindo-o até a chefatura central, sob o pretexto de entregar ao mesmo o seu caixote contendo os folhetos de "La Roche" A Colmeia, que foram considerados subversivos. ${ }^{71}$

Não demorou e surgiram atuações e posicionamentos em defesa de Canellas, a exemplo do artigo "Tyrania das ideias a questão Canellas", de autoria de João Barreto de Menezes, tecendo o seguinte comentário frente à injusta prisão e expulsão:

\begin{abstract}
Pelas colunas d'“A Província” tem sido a expulsão do socialista Antonio Canellas brilhantemente combatida, não só por Gonçalves Maia, cuja pena tem o condão de agitar os mais duros espíritos, como por essa vigorosa celebração de cientista que é Raul Azevedo, em magistrais artigos doutrinários sobre a evolução das ideias que aspiram a uma nova organização político-social dos povos. [...] Raul Azevedo discute em seus artigos o proclamado gérmen subversivo das ideias da obra de Sebastien Faure, A Colmeia, traduzido por Antonio Canellas, e mostra que tem sido as mesmas pregadas por várias inteligências outras que prenunciam uma reorganização social em bases mais equitativas de liberdade e justiça. [...] Diante do apelo que Antonio Canellas dirige ao juiz seccional, o que vae fatalmente acontecer é a sua liberdade de voltar a esta terra, o que importa dizer sua liberdade de locomoção e de pensamento, pois ao espírito brilhante do Sr. Dr. Sergio Loreto não aparecem razões determinantes dessa ordem de expulsão. Quais são elas? [...] E mais ridícula que a tirania dos partidos, aos olhos do futuro vingador, é a tirania das ideias a que ingenuamente entendem os governos opor a barreira dogmática de sua intangibilidade. Recife, 21-1-1920. João Barreto de Menezes. ${ }^{72}$
\end{abstract}

No artigo, fica evidenciada a defesa em favor de Canellas, demonstrando, ainda, as arbitrariedades por parte dos representantes do Estado. Acusado de "agitador" por

\footnotetext{
70 Jornal Pequeno, Recife, 12 jan. 1920, p. 1.

71 A Província, Recife, 12 jan. 1920, p. 1.

72 Jornal do Recife, Recife, 22 jan. 1920, p. 1.
} 
divulgar ideias de igualdade, justiça, de esclarecimento no tocante às atribuições e finalidades da política, do sistema capitalista, de propostas emancipadoras etc. Acrescentando, ainda, a iniciativa de organização dos operários, incentivos e mobilização propriamente dita.

Outra defesa foi exposta por Joaquim Pimenta no artigo "A deportação de Canellas". Segundo Joaquim Pimenta:

Foi de surpresa para mim a notícia de que a Polícia de Pernambuco havia deportado para o sul do país o jovem socialista Antonio Canellas. Porque sábado último, véspera de seu embarque forçado no 'Macapá', estive com o Dr. Manoel Candido, $1^{\circ}$ delegado da capital, que me garantiu nada haver contra esse moço cuja vida tem sido uma das mais belas epopeias que conheço do sacrifício humano. [...] Fiquei seriamente intrigado com aquela medida brusca do Dr. Luiz Correia, a quem solicitei uma explicação. Disse-me ele então que o seu modo de agir fora apenas provocado por telegramas que recebera do ministro da Justiça e do chefe da polícia do Rio, não cabendo, assim, à polícia pernambucana nenhuma responsabilidade no caso. [...] Canellas, como eu, como o Sr. Ministro, como o Sr. Desembargador, é incapaz de matar um pinto... É um rapaz simples, sem rancores, contra ninguém, sonhador como o somos todos nós nos verdes anos, e sonhador benemérito porque se atira a uma propaganda perigosa que só lhe traz dissabores, qual a de reformar, pela educação infantil, um povo retrógrado ou retardado em tudo, em política, em direito, em administração, ao campo da economia, nos ramos mais elementares da civilização contemporânea. ${ }^{73}$

Em Maceió, também foi publicada uma nota, “Um agitador”, acerca da prisão de Canellas, informando que o mesmo teria migrado para Alagoas e não para o sul do país, no "Macapá”. Na nota foi divulgado:

Segundo telegramas publicados pela imprensa, foi expulso a bordo do $<$ Macapá> pela polícia da vizinha capital do norte o perigoso agitador Antonio Canellas. Sabemos que esse agitador, iludindo a vigilância da nossa polícia, desembarcou no porto de Jaraguá. Tivemos denúncia de que Canellas está homiziado na casa de um artista, no farol. ${ }^{74}$

Essa informação procede, tendo em vista o habeas corpus impetrado por Joaquim Pimenta referente à expulsão de Canellas de Pernambuco. No jornal Diário de Pernambuco, houve uma menção referente à defesa do advogado na matéria “Expulsão de operário", redigindo as seguintes palavras:

Em sua audiência de ontem, Sr. Dr. Sergio Loreto, juiz federal para seção deste Estado, ouviu o operário brasileiro Antonio Canellas em favor de quem fora impetrada uma ordem de "habeas corpus", sob alegação de constrangimento ilegal em sua liberdade, visto ter sido expulso desta capital pela polícia, como agitador anarquista. Depois de ter tomadas por termo as declarações do paciente, que conseguira interromper a viagem em Maceió e regressar ao Recife, obteve a palavra o advogado do mesmo Dr. Joaquim Pimenta que, após afirmar estar a defesa do operário Antonio Canellas plenamente deduzida na petição de "habeas corpus", produzindo várias considerações sobre as informações a respeito prestadas em ofício ao Sr. Dr. Juiz da seccional pelo Sr. Dr. Chefe de Polícia. Presente à audiência o Sr. Dr. Antonio

73 Jornal do Commercio, Recife, 14 jan. 1920, p. 1.

74 Jornal do Commercio, Maceió, 12 jan. 1920, p. 1. 
Leitão, Procurador da República, requereu que, preliminarmente, em face dos telegramas do Sr. Ministro da Justiça constante da informação do Sr. Dr. Chefe de Polícia se telegrafasse a Sua Excelência pedindo esclarecimento se havia algum processo instaurado no Rio contra o paciente, para expulsão do território nacional. O requerimento deixou de ser deferido pelo Sr. Dr. Juiz visto haver o paciente feito a prova de sua qualidade de cidadão brasileiro, estando, portanto, excluída, qualquer possibilidade de expulsão. Para final decisão, mandou o Sr. Dr. Sergio Loreto que lhe fossem os autos conclusos. ${ }^{75}$

Gonçalves Maia publicou um artigo “Perseguições a operários”, também em defesa de Canellas, chamando atenção para as arbitrariedades cometidas pelas autoridades, tomando-as como um exemplo extensivo para outros operários, vítimas das arbitrariedades governamentais. Conclui sua fala com as palavras que seguem:

É isso que quer a nova administração pernambucana? A violência feita a um operário é uma ameaça a toda classe. E se o governo tem soldados e carabinas para fazer derramar o sangue, e tem prisões, se tem outros instrumentos de coação, o operariado não precisa senão de um bocado de solidariedade. E para vencer todos os governos do mundo, basta-lhe cruzar os braços e não trabalhar. Quem tem essa força desafia o poder e vence. $O$ que é preciso é não provocar. Gonçalves Maia. ${ }^{76}$

Com essas palavras, otimistas e ao mesmo tempo desafiadoras, Canellas e outros militantes provocaram os meios coercitivos, não se enclausuraram frente às dificuldades advindas de seus posicionamentos, fossem em jornais, panfletos, reuniões, greves, passeatas, ou mesmo sob a ameaça de prisão ou expulsão do país.

Enfim, com o término do processo, Canellas parte com destino ao Sudeste e, posteriormente, para outras regiões do país, retornando à Europa em 1922 para participar do IV Congresso da Internacional Comunista. Posteriormente, volta ao Brasil para dar continuidade ao que começou com apenas 17 anos de idade em Viçosa-AL, até o fim de sua vida em 1936.

A atuação e experiência de Canellas, enquanto militante da causa operária, alarga o conhecimento das mobilizações classistas no Nordeste, permitindo uma reflexão acerca da historiografia tradicional que situa essas mobilizações originalmente apenas na Região Sul (atual Sudeste) do país.

Recebido em 27/07/2016

Aprovado em 10/02/2017 